\title{
Knowledge and Level of Compliance of Tricycle Drivers on Traffic Rules and Regulations: A Case of the Tricycle City of the Philippines
}

\author{
Januaryn Jose B. Aydinan, RC, MSCJE
}

Faculty Member, College of Criminology, Nueva Ecija University of Science and Technology, Philippines

\begin{abstract}
The importance of traffic laws is undeniable because it is designed to protect both the lives of the drivers and passengers. Having sufficient knowledge of rules on the road and much more on practicing those rules make a driver skilled and would surely minimize the accidents or crash on the road. This study was accomplished with the objective of determining the knowledge and level of compliance of the tricycle drivers on traffic rules and regulations in terms of Ten Commandments of traffic, pavement markings and, traffic signs/signals and islands in Cabanatuan City which is known as the Tricycle City of the Philippines. With the objective of gaining new insights with the current situation in the said subject, the researcher used a descriptive research method. The respondents of this study were the 100 driver-members of selected Tricycle Operators and Drivers Association (TODA) in Cabanatuan City who were randomly chosen from different barangays. It has been found out in this study that the motorists are knowledgeable in terms of the traffic rules and regulations but on the contrary, they are not always compliant. Based on the results of this study, the researcher suggests the refurbishing of the driver licensing system and the strict implementation of the existing laws on road traffic management.
\end{abstract}

Keywords - knowledge, level of compliance, traffic rules and regulations, tricycle operations.

\section{INTRODUCTION}

Cabanatuan City prides itself as the Tricycle City of the Philippines (Dayang, 2018). In fact, tricycle operation in this city is a source of livelihood for around 10,000 families (Balaria, Pascual, Santos, Ortiz, Gabriel and Mangahas, 2017). Tricycles, which are made by attaching a sidecar to a motorcycle, are one of the means of public transportation in the Philippines (Nguyen, 2020). Since tricycle is a threewheeled vehicle, it is said to be more accident-prone compared to four-wheeled vehicles, this is also the reason why senior administration lawmaker in the Philippines are proposing safety and professional training for drivers and operators of tricycles (Romero, 2015).Unfortunately, despite the city claim and arrogance for being the Tricycle City of the Philippines, many local tricycle drivers seem hell-bent in making Cabanatuan as the City of the Most Notoriously Opportunistic and Abusive Tricycle Drivers in the country (Dayang, 2018). Needless to say that they are also the number one violators of traffic rules and many of the tricycle drivers are becoming a source of stress to other motorists and travelers. It is a sad reality that many tricycle drivers seem to think that for the reason that their vehicles are small, they can blatantly ignore rules - going against traffic on one-way streets, squeezing between cars, even trucks, and making turns whenever they feel like it-putting their passengers' and their own lives at risk (Bolido, 2014). Each day, this is a normal scenario on the road of Cabanatuan City.

Based on data from the Philippine Statistics Authority, motorcycle-related injuries comprise $69 \%$ of the total identified transport incidents nationwide (Sy, 2017). Because of these disturbing figures, it pays for motorists to be aware of the most common reasons for accidents so they may use this information to reduce their level of risk (Michon, 2020). The instability of the sidecar attached to the motorcycles, which serve as passengers' seats is among the leading cause of accidents (Felongco, 2015). Driver's lack of awareness about traffic rules, regulations and laws, and their non-compliance with these traffic rules and regulations were the most significant causes of road traffic accidents (AlKhaldi, 2006).

Traffic rules, regulations and guidelines have to be set in place and must be strictly followed by motorists so that serious accidents and injuries can be prevented (Nilkamal Pvt Ltd, 2018). The knowledge and attitude which can be 
done through a compliance survey is a powerful tool that can be used to determine the knowledge and the attitude of the populations regarding traffic rules and regulations on the road (Vandamme, 2009). In order to address these issues related to lack of knowledge and compliance of the tricycle drivers in Cabanatuan City towards road traffic rules and regulations, the researcher has realized the need to conduct this study which purpose was to determine the knowledge and level of compliance of tricycle drivers in Cabanatuan City on traffic rules and regulations. Specifically, it sought to answer the profile of the respondents, their level of knowledge on traffic rules and regulations and their level of compliance on traffic rules and regulations.

\section{METHODOLOGY}

In determining the knowledge and level of compliance of tricycle drivers on traffic rules and regulations, this study makes use of the descriptive research method. Descriptive research describes the state of affairs as it exists at the present time which employs surveys and fact-finding inquiries of different kinds. The researcher only reports what has happened or what is happening at the current state (Bist, 2014). The respondents of the study were the randomly selected 100 tricycle drivers of different Tricycle Operators and Drivers Association (TODA) in Cabanatuan City. With the objective of gaining familiarity with a phenomenon or to achieve new insights into the topic (Kothari and Garag, 2014); the researcher used a descriptive research method. The questionnaire was self-constructed based on the Traffic Management and Accident Investigation book of Delizo (2014) and before the conduct of a survey, the questionnaire was evaluated by experts in the field of Criminology. The following numerical and adjectival values were used:

\begin{tabular}{|c|c|c|c|}
\hline Ranges & Rate & Knowledge & Level of Compliance \\
\hline $4.20-5.00$ & 5 & Highly Knowledgeable & Always \\
\hline $3.40-4.19$ & 4 & Knowledgeable & Often \\
\hline $2.60-3.39$ & 3 & Moderately Knowledgeable & Sometimes \\
\hline $1.80-2.59$ & 2 & Fairly Knowledgeable & Seldom \\
\hline $1.00-1.79$ & 1 & Not Knowledgeable & Never \\
\hline
\end{tabular}

Frequency, percentage and weighted mean were the statistical tools used in this study. The information and data gathered by the researcher were organized, tabulated and collated for better analysis and interpretation.

\section{RESULTS AND DISCUSSION}

This section presents the results of the survey conducted regarding the knowledge and the level of compliance of tricycle drivers in Cabanatuan City on traffic rules and regulations.

\section{Profile of the Respondents}

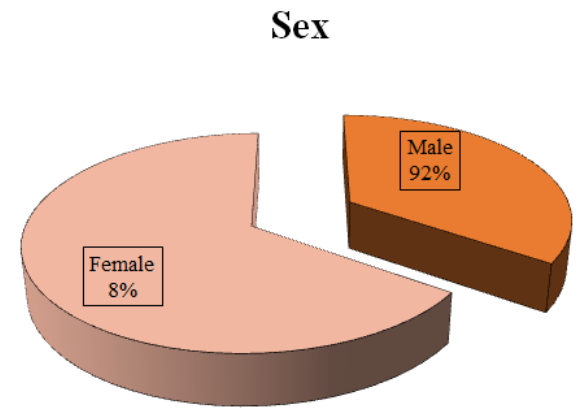

The data above revealed that the majority of the tricycle drivers were male. Driving is still dominated by male drivers; further strengthening the idea is the earlier research which shows that transport remains a male-dominated industry (Ames, Mateo-Babiano and Susilo, 2014).

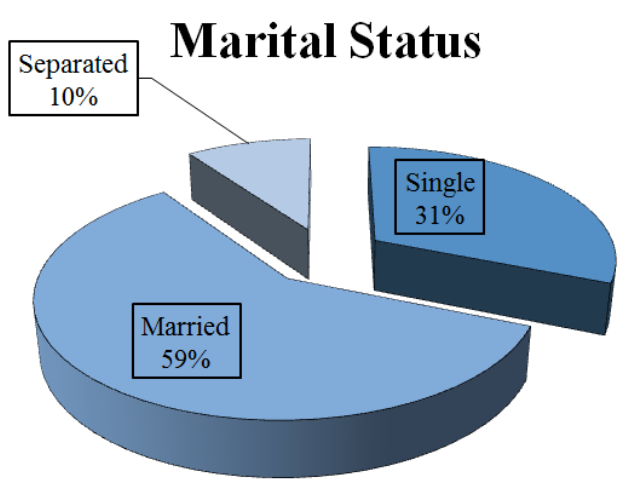

The data above presented that majority of the respondents were married. Most of the respondents use tricycle operations as their occupations for the reason that they are providers for their families (TopGear.com.ph, 2018). 


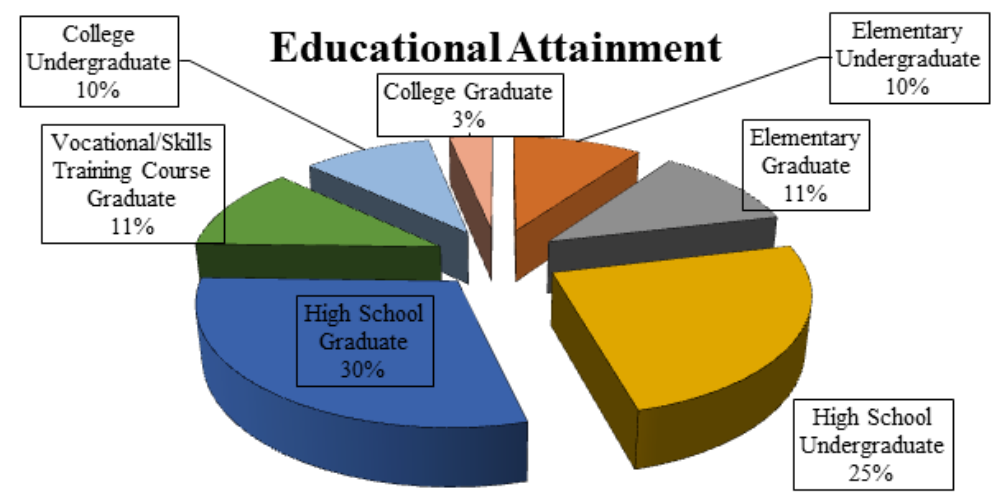

The data above displayed that majority of the tricycle drivers did not finish college. In fact, only $3 \%$ of the respondents were able to finish a degree. They chose to become tricycle drivers due to poverty and because they were not able to finish their studies (San Diego, n.d.).

2. Knowledge of Tricycle Drivers on Traffic Rules and Regulations

Table 1. Knowledge of Tricycle Drivers on Ten Commandments of Traffic

\begin{tabular}{|c|l|c|c|}
\hline No. & \multicolumn{1}{|c|}{ Indicators } & WM & Verbal Description \\
\hline 1 & Knowledge about the "Keep right" rule & 4.08 & Knowledgeable \\
\hline 2 & Knowledge on how to observe road courtesy & 4.11 & Knowledgeable \\
\hline 3 & Knowledge about places on the roadway that vehicles should not be parked & 4.31 & Highly Knowledgeable \\
\hline 4 & Knowledge on what does it mean by "If in doubt, do not overtake" & 3.97 & Knowledgeable \\
\hline 5 & Knowledge about the "bus stop rule" & 3.93 & Knowledgeable \\
\hline 6 & $\begin{array}{l}\text { Knowledge about the "Rules to prevent or untangle traffic congestion or } \\
\text { traffic jam" }\end{array}$ & 3.85 & Knowledgeable \\
\hline 7 & Knowledge about what is "Observe the Traffic Management Measure" & 3.98 & Knowledgeable \\
\hline 8 & Knowledge about what is "The Philosophy of a Pinoy Driver" & 3.75 & Knowledgeable \\
\hline 9 & Knowledge about the "On Pedestrians Rule" & 4.25 & Highly Knowledgeable \\
\hline 10 & Knowledge about the "International Driving Safety Reminder" & 4.02 & Knowledgeable \\
\hline & Average Weighted Mean & 4.03 & Knowledgeable \\
\hline
\end{tabular}

The data above revealed that the tricycle drivers were highly knowledgeable about the places on the roadway that vehicles should not be parked with a weighted mean of 4.31. It is a good thing that tricycle drivers are well-informed that vehicles should not be parked near intersection, crosswalk, pedestrian lanes, fire stations, fired hydrant and even private driveways (Delizo, 2014). This commandment seems to be notable by drivers because these places are marked on the streets and this rule was apprised to the motorists during the issuance of driver's license. Similarly, the respondents were also highly knowledgeable on the pedestrian rule with a weighted mean of 4.25.Unfortunately, the drivers were discovered to be just knowledgeable about the philosophy of a Pinoy driver, this phrase means being considerate to his fellow drivers, for example in a Rotonda, first come first serve, but based on the surveillance among tricycle drivers, it seems that this philosophy is not being observed from them. 
Table 2. Knowledge of Tricycle Drivers on Pavement Markings

\begin{tabular}{|c|l|c|c|}
\hline No. & \multicolumn{1}{|c|}{ Indicators } & WM & \multicolumn{1}{|c|}{$\begin{array}{c}\text { Verbal } \\
\text { Description }\end{array}$} \\
\hline 1 & Knowledge about what is meant by "Single white dotted line" & 3.74 & Knowledgeable \\
\hline 2 & $\begin{array}{l}\text { Knowledge about what is meant by "Single white continuous line in a two-lane } \\
\text { traffic way" }\end{array}$ & 3.80 & Knowledgeable \\
\hline 3 & Knowledge about what is meant by "Single continuous line on a four-lane road" & 3.44 & Knowledgeable \\
\hline 4 & Knowledge about what is meant by "Double yellow/white line" & 3.57 & Knowledgeable \\
\hline 5 & $\begin{array}{l}\text { Knowledge about what is meant by "Single white/yellow line with white/yellow } \\
\text { dotted line" }\end{array}$ & 3.18 & $\begin{array}{c}\text { Moderately } \\
\text { Knowledgeable }\end{array}$ \\
\hline 6 & $\begin{array}{l}\text { Knowledge about what is meant by "Yellow continuous line on the road provided } \\
\text { with a passing lane" }\end{array}$ & 3.67 & Knowledgeable \\
\hline 7 & Knowledge about what is meant by "Crosswalk or pedestrian lane" & 4.11 & Knowledgeable \\
\hline 8 & Knowledge about what is meant by "Directional arrows" & 3.93 & Knowledgeable \\
\hline 9 & Knowledge about what is meant by "Stop lines" & 3.92 & Knowledgeable \\
\hline 10 & Knowledge about what is meant by "Barrel lines" & 3.56 & Knowledgeable \\
\hline & \multicolumn{1}{|c|}{ Average Weighted Mean } & 3.69 & Knowledgeable \\
\hline
\end{tabular}

The data above illustrated that tricycle drivers were knowledgeable about what is meant by a crosswalk or a pedestrian lane with a weighted mean of 4.11. In an article written by Lindeke (2014), he mentioned that according to Mongelli, who is a tool engineer, high-visibility crosswalks can come in all sorts of subtle varieties, ranging from the basic crosswalk which is the two simple lines up to "continental" or "piano" crosswalks that are those thick white lines perpendicular to the traffic lane and also the "zebra" crosswalks which are the white lines at an angle. These markings were distinguished by the drivers because of their visibility on the roads and can be pondered ascommon knowledge among motorists. On the contrary, drivers were only moderately knowledgeable about what is meant by a single white/yellow line with white/yellow dotted line with a weighted mean of 3.18. According to Tamayo (2016), reading road markings is such an important skill for new drivers, yet appears to be one that even veteran drivers seem to lack. He added that it could be because the road signage and markings in the Philippines seem to be in a perpetual state of flux, and even the authorities painting them often seem puzzled by where they should actually go.

Table 3. Knowledge of Tricycle Drivers on Traffic Signs/Signals and Islands

\begin{tabular}{|c|l|c|c|}
\hline No. & \multicolumn{1}{|c|}{ Indicators } & WM & Verbal Description \\
\hline 1 & Knowledge about Danger Warning Signs & 3.97 & Knowledgeable \\
\hline 2 & Knowledge about Prohibitive and Restrictive Signs & 3.82 & Knowledgeable \\
\hline 3 & Knowledge about Mandatory Signs & 3.39 & Moderately Knowledgeable \\
\hline 4 & Knowledge about Priority Signs & 3.52 & Knowledgeable \\
\hline 5 & Knowledge about Informative Signs & 3.51 & Knowledgeable \\
\hline 6 & Knowledge about the use of Pedestrian Island & 3.38 & Moderately Knowledgeable \\
\hline 7 & Knowledge about the use of Division Island & 3.23 & Moderately Knowledgeable \\
\hline 8 & Knowledge about the use of Channelizing Island & 3.34 & Moderately Knowledgeable \\
\hline 9 & Knowledge about the use of Rotary Island & 3.51 & Knowledgeable \\
\hline 10 & Knowledge about the meaning of each color on the traffic signal light & 4.13 & Knowledgeable \\
\hline \multicolumn{2}{r|}{ Average Weighted Mean } & 3.58 & Knowledgeable \\
\hline
\end{tabular}


It can be noticed from the table above that motorists were knowledgeable about the meaning of each color on the traffic signal light with a weighted mean of 4.13. This is a knowledge that every child in the Philippines has gained since they all need to commute and use the pedestrian at some point in their lives (Kim, 2019). Traffic lights are some of the most common fixtures existing in any major road and can be usually seen on intersections, corners, turns, and other crucial junctions and learning how traffic lights work and what the signs and colors mean can only take a short period of time (Ayam, n.d.). Quite the reverse of the knowledge of drivers on other rules and regulations on traffic signals and islands, the respondents were moderately knowledgeable on the use of Division Island with a weighted mean of 3.23. Division Island is a sub-classification of Traffic Islands which are constructed primarily to divide the streams of the motor vehicles (Delizo, 2014). Due to the fact that these areas are not given priorities in the lectures during the issuance of driver's license, the majority of the licensed drivers do not have full knowledge on traffic islands such as division, channelizing and rotary.

\section{Level of Compliance of Tricycle Drivers on Traffic Rules and Regulations}

Table 4. Level of Compliance on Ten Commandments

\begin{tabular}{|c|l|c|c|}
\hline No. & \multicolumn{1}{|c|}{ Indicators } & WM & $\begin{array}{c}\text { Verbal } \\
\text { Description }\end{array}$ \\
\hline 1 & Keeping right while driving & 3.70 & Often \\
\hline 2 & $\begin{array}{l}\text { Yielding to emergency vehicles, pedestrians, vehicles with right of way, traffic } \\
\text { with momentum and traffic signs }\end{array}$ & 4.21 & Always \\
\hline 3 & $\begin{array}{l}\text { Parking near the intersection, pedestrian lanes, fire stations, fire hydrant, and } \\
\text { private driveways }\end{array}$ & 3.48 & Often \\
\hline 4 & Overtaking even when there is upcoming traffic & 2.92 & Sometimes \\
\hline 5 & Parking or passing on a bus stop & 2.97 & Sometimes \\
\hline 6 & $\begin{array}{l}\text { Giving way to intersections during traffic and avoiding overtaking/counter } \\
\text { flowing }\end{array}$ & 3.44 & Often \\
\hline 7 & $\begin{array}{l}\text { Driving on the shoulder in the main highway and even when it is your vehicles } \\
\text { coding }\end{array}$ & 3.08 & Sometimes \\
\hline 8 & $\begin{array}{l}\text { Giving way to vehicles that come first on rotundas or intersections in the absence } \\
\text { of traffic signal lights }\end{array}$ & 3.79 & Often \\
\hline 9 & Giving way to pedestrians and yield on a bus stop and jitney stop & 4.05 & Often \\
\hline 10 & Driving within the speed limit to observe safety first & 3.93 & Often \\
\hline \multicolumn{2}{|l|}{ Average Weighted Mean } & 3.56 & Often \\
\hline
\end{tabular}

The table above exemplifies the level of compliance of tricycle drivers on the Ten Commandments of Traffic. It can be remarked that tricycle operators are always yielding to emergency vehicles, pedestrians, vehicles with right of way, traffic with momentum and traffic signs with a weighted mean of 4.21. It is essential that tricycle drivers are knowledgeable on the road traffic rules and regulations, but it is much desirable if they are compliant. It is a good thing that tricycle drivers give way to ambulance, police cars and fire trucks during emergencies. It is an obligation of every driver to give way to emergency vehicles at all times once they hear the siren (Carlos, 2017). Failure to do so is a violation of the Republic Act No. 4136 Article V Section 49 which is the Right of way for police and other emergency vehicles. Contrariwise, drivers were sometimes overtaking even when there is upcoming traffic with a weighted mean of 2.92. Tricycle drivers are always on the rush that even if there is approaching traffic and because they are confident that their vehicles are small that it can pass through other big vehicles, they are remarkably more expected to engage in unsafe behaviors than other vehicle drivers even during traffic especially on straight roads (Uzondu, Jamson and Laia, 2019). 
Table 5. Level of Compliance on Pavement Markings

\begin{tabular}{|c|l|c|c|}
\hline No. & \multicolumn{1}{|c|}{ Indicators } & WM & $\begin{array}{c}\text { Verbal } \\
\text { Description }\end{array}$ \\
\hline 1 & $\begin{array}{l}\text { Overtaking only when a single white dotted line is present and an } \\
\text { opposing lane is clear }\end{array}$ & 3.13 & Sometimes \\
\hline 2 & Overtaking when there is a single white continuous line & 2.95 & Sometimes \\
\hline 3 & $\begin{array}{l}\text { Overtaking by passing over the solid/continuous white lines on a four- } \\
\text { lane road }\end{array}$ & 2.98 & Sometimes \\
\hline 4 & Overtaking when double yellow/white line is present & 2.36 & Seldom \\
\hline 5 & $\begin{array}{l}\text { Overtaking when there is a single yellow/white line with a dotted line } \\
\text { and the solid line is in my side }\end{array}$ & 3.30 & Sometimes \\
\hline 6 & Passing on the passing lane if it is present on the roadway & 3.10 & Sometimes \\
\hline 7 & Stopping and loading or unloading a passenger on pedestrian lane & 3.07 & Sometimes \\
\hline 8 & Following directional arrows on intersections & 3.28 & Sometimes \\
\hline 9 & Stopping at stop lines before intersections or pedestrian lanes & 3.79 & Often \\
\hline 10 & Avoiding bumping on barrel lines in case of an accident & 3.93 & Often \\
\hline \multicolumn{2}{|}{ Average Weighted Mean } & 3.19 & Sometimes \\
\hline
\end{tabular}

It is displayed on the table above that the driver-respondents often avoid bumping on barrel lines in case of an accident with a weighted mean of 3.93 . This is the scenario due to the fact that they are not mindful of the use of barrel lines. Barrel lines are a new concept in reducing the seriousness of accidents and engineered to act as impact cushion (Delizo, 2014). Equally, the tricycle drivers sometimes disregard the pedestrians if they know that they are ahead of them and they habitually use their horn extensively; furthermore, they also disregard this rule if the intersection is clear and there is no pedestrian around. Meanwhile, the respondents occasionally overtake when a double yellow/white line is present with a weighted mean of 2.36. It also believed that the level of compliance depends on the positive law enforcement as a manner to build road safety culture (Alonso, Esteban, Montoro and Sergio, 2017) and competence of the law enforcers can be achieved if they are managed properly in their nature of work (Eduardo and Gabriel, 2017).

Table 6. Level of Compliance of Tricycle Drivers on Traffic Signs/Signals and Islands

\begin{tabular}{|c|l|c|c|}
\hline No. & \multicolumn{1}{|c|}{ Indicators } & WM & $\begin{array}{c}\text { Verbal } \\
\text { Description }\end{array}$ \\
\hline 1 & $\begin{array}{l}\text { Observing caution when triangular traffic signs are present on the road } \\
\text { like "Intersection Ahead" }\end{array}$ & 4.05 & Often \\
\hline 2 & Following prohibitive signs and restrictive signs like "No Entry" & 4.18 & Often \\
\hline 3 & Following mandatory signs like "Minimum Speed" & 3.77 & Often \\
\hline 4 & Following stop/yield signs especially on intersections & 3.95 & Often \\
\hline 5 & Dropping passengers on unloading areas designated on the road & 4.11 & Often \\
\hline 6 & Parking on a pedestrian island & 2.84 & Sometimes \\
\hline 7 & Counter flowing when there is a division island on the road & 2.95 & Sometimes \\
\hline 8 & Following channelizing island especially on intersections & 3.61 & Often \\
\hline 9 & Following rotary islands when it is present & 3.21 & Sometimes \\
\hline 10 & Jumping on traffic signal lights & 2.95 & Sometimes \\
\hline & & 3.56 & Often \\
\hline
\end{tabular}

The table above shows that respondents often follow prohibitive signs and restrictive signs like "No Entry" with a weighted mean of 4.18 but there are still some tricycle ISSN: $2456-7620$ drivers in Cabanatuan City who consistently disregard the "No Entry" signs because they continue to pass the road. Correspondingly, tricycle drivers often drop their passengers 
on areas intended for unloading with a weighted mean of 4.11 but still, there are violators of this law. It only shows that motorists are ignorant and undisciplined (Bondoc, 2020). In the study of Uzondu, Jamsonand Laia (2019), it was found out that tricycle drivers were also over-represented in picking/dropping off passengers compared to other vehicle drivers. It is true that they know the rules and regulations but they stillviolate them. The drivers sometimes park on Pedestrian Island with a weighted mean of 2.84 . They do this violation even if they know the purpose of the Pedestrian Island. In many cases, tricycle drivers have been apprehended and penalized for various violations of traffic laws, rules and regulations.

\section{CONCLUSIONS AND RECOMMENDATIONS}

It has been realized in this paper that tricycle drivers play a significant role in the lives of passengers every day. They are the medium of transportation for many travelers and commuters that's why it is substantial that they know the traffic rules and regulations in order to avoid or at least minimize the risk of accidents on the road brought by them. It has been discovered through this study that the driverrespondents are neither innocent nor ignorant on road traffic rules and regulations but unfortunately despite them being knowledgeable, they are not always compliant. This seems to be alarming because the majority of the drivers are licensed and it is expected that they are highly knowledgeable on traffic rules and regulations but it is much anticipated that they are obedient.

Based on the results of this study, the researcher suggests the strict implementation of the driver licensing scheme and avoid bribery and fixing during driver's license processing. On the part of the concerned agency on Traffic Management and Accident Investigation, stricter regulations and enforcement would help reduce traffic violations. Additionally, appropriate road safety education can be conducted for the welfare of the general public and it is recommended to tap the State Universities and Colleges to deliver such programs for the members of the Tricycle Operators and Drivers Association (TODA) in Cabanatuan City. These drivers must be trained with the right strategies, schemes, or tactics (Subia, 2018)that are proven to be effective (Subia, 2020) to reduce the risks of accidents on the road. This is beneficial on the part of the tricycle drivers because their knowledge of traffic rules and regulations can be refreshed. Congruently, the authorities must give priorities on the knowledge, attitudes, and practices of drivers towards traffic rules and regulations in Cabanatuan City because it ISSN: 2456-7620

https://dx.doi.org/10.22161/ijels.52.30 may be of great help in the controlling the traffic rules violation and mitigation of road accidents involving the tricycle drivers (Riaz and Shahid, 2018) in the what so-called Tricycle City of the Philippines.

\section{REFERENCES}

[1] Dayang, Johnny (2018). Cabanatuan as Tricycle City. Retrieved on October 21, 2019 from:

[2] Balaria, F., Pascual, M., Santos, M., Ortiz, A., Gabriel, A. and Mangahas, T. (2017). Sustainability of E-Trike as Alternative Mode of Public Transportation System: The Case of Cabanatuan City, Philippines. Open Journal of Civil Engineering, 7, 362-377. doi: 10.4236/ojce.2017.73025.

[3] Nguyen, Binh (2020). Have You Ridden a Tricycle and Eaten Lechon in the Philippines? I Have. Retrieved on March 31, 2020 from: https://pages.kiva.org/blog/have-you-ridden-atricycle-and-eaten-lechon-in-the-philippines-i-have

[4] Romero, Paolo (2015). Lawmaker wants Training for Trike Drivers. Retrieved on January 13, 2020 from: https://www.philstar.com/metro/2015/12/25/1536371/lawmake $\mathrm{r}$-wants-training-trike-drivers

[5] Bolido, Linda (2014). Pedicabs, Tricycles should Follow Traffic Rules. Retrieved on February 18, 2020 from: https://lifestyle.inquirer.net/161174/pedicabs-tricyclesshould-follow-traffic-rules/

[6] Sy, Kimiko (2017). IN NUMBERS: Road Crash Incidents in the Philippines. Retrieved on January 29, 2020 from: https://www.rappler.com/move-ph/issues/roadsafety/166151-road-crashes-philippines-awareness-safety

[7] Michon, Kathleen (2020). Motorcycle Accidents: Common Causes. Retrieved on March 20, 2020 from: https://www.nolo.com/legal-encyclopedia/motorcycleaccidents-common-causes-30330.html

[8] Felongco, Gilbert P. (2015). Philippines: Tricycles and Motorcycles Responsible for 45 per cent of Harmful Emissions. Retrieved on January 09, 2020 from: https://gulfnews.com/world/asia/philippines/philippinestricycles-and-motorcycles-responsible-for-45-per-cent-ofharmful-emissions-1.1624254

[9] Al-Khaldi, YM. (2006). Attitude and Practice towards Road Traffic Regulations among Students of Health Sciences College in Aseer Region. J Fam Community Med 2006;13:109-13

[10] Nilkamal Pvt Ltd. (2018). The Importance of Road Safety Products to Prevent Accidents \& Injuries. Retrieved on February 27, 2020 from: https://medium.com/@Nilkamal_MH/the-importance-ofroad-safety-products-to-prevent-accidents-injuriescf6a43de7106

[11] Vandamme, E. (2009) Concepts and Challenges in the Use of Knowledge-Attitude-Practice Surveys: Literature Review. 
Department of Animal Health Institute, Institute of Tropical medicine, Antwerp.

[12] Bist, Resham Bahadur (2014). Research Procedure: An Introduction. Journal of NELTA Surkhet Vol. 4, pp. 34-40

[13] Kothari, C. R., \& Garg, G. (2014). Research Methodology Methods and Techniques (3rded.). New Dellhi: New Age International (P) Ltd.

[14] Delizo, Darlito Bernard G. (2014). Traffic Management and Accident Investigation (Second Edition). Wiseman's Books Trading, Inc.

[15] Ames, A., Mateo-Babiano, I. and Susilo, Y., 2014. Transport Workers' Perspective on Indigenous Transport and Climate Change Adaptation. Transportation Research Record: Journal of the Transportation Research Board, (2451), pp.1-9.

[16] TopGear.com.ph (2018). We Spend the Day as a Tricycle Driver. Retrieved on January 12, 2020 from: https://www.topgear.com.ph/features/feature-articles/wespend-the-day-as-a-tricycle-driver-a2619-20181223

[17] San Diego, Ann (n.d.). Daily Circumstances that Encounter by the Tricycle Driver in Quezon City. Retrieved on February 1, 2020

from: https://www.academia.edu/37175396/DAILY_CIRCUMSTA NCES_THAT_ENCOUNTER_BY_THE_TRICYCLE_DRIV ER_IN_QUEZON_CITY_Background_of_the_Study

[18] Lindeke, Bill (2014). Everything you've always wanted to know about Crosswalks. Retrieved on March 13, 2020 from: https://www.minnpost.com/cityscape/2014/07/everythingyouve-always-wanted-know-about-crosswalks/

[19] Tamayo, Niky (2016). Must-know: All the basic road markings in $\mathrm{PH}$ and what each one means. Retrieved on March 03, 2020 from: https://www.topgear.com.ph/features/tipsheet/must-know-all-the-basic-road-markings-in-ph-andwhat-each-one-means-a36-20160429

[20] Kim, Charisse (2019). A drivers' guide to the traffic signal lights in the Philippines. Retrieved on December 13, 2019 from: https://philkotse.com/safe-driving/a-drivers-guide-tothe-traffic-signal-lights-in-the-philippines-4438

[21] Ayam (n.d.). A Guide to Traffic Lights. Retrieved on March 05, 2020 from: https://roberts.com.ph/blog/safety-first-roadsigns/

[22] Carlos (2017). Types of Emergency Vehicle Sirens and Who Are Allowed to Use One. Retrieved on December 13, 2019 from: $\quad$ https://www.pinoydriver.com/resources/types-ofemergency-vehicle-sirens-and-who-are-allowed-to-useone/

[23] Republic Act No. 4136. An Act to Compile the Laws relative to Land Transportation and Traffic Rules, to create a Land Transportation Commission and for other Purposes. Retried on April 07, 2020 from: https://www.lawphil.net/statutes/repacts/ra1964/ra_4136_1964 . $\mathrm{html}$

[24] Uzondu, C., Jamson, S. and Laia, F. (2019). Investigating Unsafe Behaviours in Traffic Conflict Situations: An
Observational Study in Nigeria. Journal of Traffic and Transportation Engineering (English Edition), Volume 6, Issue 5, Pages 482-492

[25] Alonso, F., Esteban, C., Montoro, L. and Useche, S.A. (2017). Knowledge, Perceived Effectiveness and Qualification of Traffic Rules, Police Supervision, Sanctions and Justice, Cogent Soc. Sci., 3, p. 1393855, 10.1080/23311886.2017.1393855

[26] Eduardo, J. P., and Gabriel, A. G. (2017). Assessing the Leadership Skills of the Chiefs of Police in theTowns of Nueva Ecija, Philippines: A Dichotomy between Managerial Competenceand Decision Making Ability. Open Journalof Leadership, 6, 142-159. https://doi.org/10.4236/oj1.2017.64011

[27] Bondoc, Jarius (2020). Enforce tricycle laws first, before twowheel taxis. Retrieved on February 25, 2020 from: https://www.philstar.com/opinion/2020/01/10/1983479/enforc e-tricycle-laws-first-two-wheel-taxis

[28] Subia, G.S. (2018). Comprehensible Technique in Solving Consecutive Number Problems in Algebra. Journal of Applied Mathematics and Physics, 6,447-457. https://doi.org/10.4236/jamp.2018.63041

[29] Subia, G. S. (2020). Fortuitous: A proposed activity-based book in mathematics of chance. International Journal of Scientific and Technology Research, 9(3), 450-453.

[30] Riaz, I. and Shahid, S. (2018). Knowledge, Attitudes, and Practice of Drivers towards Traffic Rules and Regulations in Multan, Pakistan. SSRN Electronic Journal, DOI: $10.2139 / \mathrm{ssrn} .3152120$ 